\title{
PELATIHAN MOTIVASI KEWIRAUSAHAAN DAN KETERAMPILAN MANAJERIAL WIRAUSAHA BARU DI KECAMATAN LENGKONG KOTA BANDUNG
}

\author{
Rr Rachmawati \\ watieroro@gmail.com \\ Herry Ahcmad Buchory \\ achmad.buchory@gmail.com \\ Terra Saptina Maulani \\ terra.saptina@ekuitas.ac.id
}

SEKOLAH TINGGI ILMU EKONOMI EKUITAS

\begin{abstract}
ABSTRAK
Kegiatan kewirausahaan merupakan kegiatan yang dapat mendorong perekonomian. Mitra pengabdian ini adalah para wirausahawan yang tergabung dalam program WUB kota Bandung di Kecamatan Lengkong. Berdasarkan data Dinas KUKM Kota Bandung (2017), terdapat 40 wirausahawan di Kecamatan Lengkong yang memiliki potensi untuk berkembang, dimana mereka adalah merupakan wirausahawan yang terjaring dalam program Wirausaha Baru Kota Bandung yang memiliki usaha 0-5 tahun. Akan tetapi permasalahan yang terjadi adalah menurunnya motivasi usaha pelaku usaha jika dihadapkan persoalan usaha, sebanyak 40 wirausahawan yang terdaftar sebagai wirausahwan baru, saat ini hanya 22 wirausahawan yang aktif menjalankan usahanya, atau dengan kata lain menurun sebesar 45\%, maka dari itu perlunya meningkatkan motivasi kewirausahaan melalui pelatihan. Permasalahan lain adalah kurang wirausahawan dalam hal manajerial, bahwa pelaku usaha belum dapat memisahkan keuangan pribadi dengan usaha, pencatatan laporan keuangan yang masih tumpang tindih, kurang dapat melakukan pemasaran, dan sebagian besar juga masih merasa bingung dalam merencanakan persediaan, maka dari itu perlunya pelatihan keterampilan manajerial yang mudah dipahami para pelaku usaha agar usahanya memiliki daya saing.
\end{abstract}

Kata kunci: Pelatihan Motivasi, Pelatihan Manajerial.

\section{PENDAHULUAN}

Semakin maju suatu negara semakin banyak orang yang terdidik dan banyak pula yang menganggur, maka semakin dirasakan pentingnya dunia wirausaha, negara maju umumnya memiliki wirausaha lebih banyak dibandingkan dengan negara berkembang, misalnya Amerika Serikat $11,5 \%$, Singapura sebesar $7,2 \%$ dari total penduduk adalah wirausaha. Pembangunan akan lebih berhasil jika ditunjang oleh wirausahawan yang dapat membuka lapangan pekerjaan, oleh karena itu wirausaha merupakan potensi pembangunan. Menkop mengungkapkan bahwa saat ini kita dihadapkan bahwa jumlah wirausahawan di Indonesia masih rendah sebesar 3,1\%. Rendahnya wirausahawan di Indonesia, 
maka pemerintah menargetkan mencapai 5\% jika ada kerjasama dari semua pihak antara pemerintah pusat, pemerintah daerah, dan kampus (http://ekonomi.kompas.com, diunduh pada tanggal 26 januari 2018).

Guna mendukung program pemerintah pusat yang menargetkan jumlah wirausahawan mencapai 5\%, maka pemerintah Kota Bandung mendukung program tersebut yang tertuang dalam RPJMD 2013-2018 dalam menciptakan 100.000 wirausaha baru yang bertujuan untuk mendukung kesejahteraan masyarakat dan menciptakan lapangan kerja. Setiap tahunnya Dinas KUMKM Kota Bandung menargetkan 1000 orang yang memiliki potensi untuk diberikan pelatihan, dimana pelaksanaannya terdalpat di 25 wilayah di Kota Bandung, salah satunya adalah Kecamatan Lengkong. Kecamatan Lengkong merupakan kecamatan yang secara kewilayahan terdapat di wilayah Bandung Tengah dengan memiliki luas lahan sebesar $575 \mathrm{Ha}$. Secara administratif Kecamatan Lengkong dibatasi oleh:

1. Bagian Selatan: Kecamatan Bandung Kidul

2. Bagian Utara: Kecamatan Sumur Bandung

3. Bagian Timur: Kecamatan Batununggal

4. Bagian Barat: Kecamatan Regol Secara administratif Kecamatan Lengkong terdiri 7 (tujuh) kelurahan, 65 RW, dan 431 RT. Jumlah penduduk di Kecamatan Lengkong sebanyak 64.981 Jiwa diantaranya terdiri dari 32.497 laki- laki dan 32.502 perempuan, serta mayoritas berpendidikan lulusan SMA sebanyak 10.694 jiwa. Kecamatan lengkong memiliki potensi kewirausahaan dikarenakan sebagian besar penduduknya bekerja sebagai pedagang sebanyak 6.753 jiwa yang memiliki potensi untuk berkembang. Menekuni usaha yang bersifat usaha kecil, mikro dan menengah merupakan salah satu profesi mayoritas penduduk dengan rincian warung makan, kios, PKL, pengrajin makanan, pengrajin kerajinan, pengrajin pakaian, usaha angkutam, percetakan/ sablon, bengkel dan usaha lainnya. Berdasarkan data Dinas KUKM Kota Bandung (2017), terdapat 40 wirausahawan di Kecamatan Lengkong yang memiliki potensi untuk berkembang, dimana mereka adalah merupakan wirausahawan yang terjaring dalam program Wirausaha Baru Kota Bandung yang memiliki usaha 0-5 tahun. Akan tetapi permasalahan yang muncul saat ini adalah rendahnya motivasi pelaku usaha karena dihadapkan suatu permasalahan seperti modal, akses pasar, bahan baku dan lainnya sehingga dari 40 wirausahawan, hanya 22 wirausahwan yang masih menjalankan aktif usahanya asampai saat ini tau sekitar $45 \%$ tidak aktif menjalakan usahanya. Melihat hal tesebut maka perlunya dilakukan kembali pelatihan untuk meningkatkan motivasi kewirausahaan terhadap pelaku usaha.

Permasalahan lain adalah kurang wirausahawan dalam hal manajerial, bahwa pelaku usaha belum dapat memisahkan keuangan pribadi dengan usaha, pencatatan laporan keuangan yang masih tumpang tindih, kurang dapat melakukan pemasaran, dan sebagian besar juga masih merasa bingung dalam merencanakan persediaan, maka dari itu perlunya pelatihan keterampilan manajerial yang mudah dipahami para pelaku usaha agar usahanya memiliki daya saing. Karena Kewirausahaan bukan ilmu ajaib yang mendatangkan uang dalam waktu sekejap, melainkan sebuah ilmu, seni, keterampilan untuk mengelola semua keterbatasan sumber daya, informasi, dan dana yang ada guna mempertahankan hidup, mencari nafkah, atau meraih posisi puncak dalam karir, maka dari itu diperlukan kombinasi ilmu pengetahuan/ skill berupa marketing, SDM, Keuangan, Manajemen Kualitas, serta teknologi informasi dan kreativitas dalam mengatasi kesulitan, hambatan, tantangan agar terhindar dari kegagalan (Hendro, 2011). Senada dengan yang diungkapkan Muzinu (2010), kinerja usaha kecil dan menengah salah satunya dipengaruhi oleh faktor faktor internal yaitu aspek SDM, aspek keuangan, aspek operasi 
dan aspek pemasaran. Maka dari itu perlunya pelatihan keterampilan manajerial agar usaha yang mereka miliki lebih berdaya saing. Tambunan (2008), mengungkapkan bahwa salah sati faktor penentu daya saing usaha adalah keahlian pengusaha.

\section{METODE KEGIATAN}

Metodologi dalam pelaksanaan pengabdian kepada masyarakat ini adalah sebagai berikut:

\begin{tabular}{|c|c|c|}
\hline TAHAPAN & METODE & HASIL \\
\hline Tahap awal & $\begin{array}{l}\text { Tim melakukan } \\
\text { survey dan } \\
\text { observasi untuk } \\
\text { lebih } \\
\text { mengetahui } \\
\text { kendala dan } \\
\text { hambatan dalam } \\
\text { menjalankan } \\
\text { usaha. }\end{array}$ & $\begin{array}{l}\text { Pemahaman } \\
\text { persamaan } \\
\text { persepsi antara } \\
\text { tim dan pelaku } \\
\text { usaha }\end{array}$ \\
\hline $\begin{array}{l}\text { Tahap } \\
\text { pelaksanaan }\end{array}$ & $\begin{array}{l}\text { - Pelatihan } \\
\text { motivasi } \\
\text { kewirausahaan } \\
\text { - Pelatihan } \\
\text { keterampilan } \\
\text { manajerial } \\
\text { yang meliputi } \\
\text { aspek } \\
\text { pemasaran, } \\
\text { aspek } \\
\text { keuangan, } \\
\text { aspek } \\
\text { operasional/ } \\
\text { produksi, dan } \\
\text { aspek sumber } \\
\text { daya manusia. }\end{array}$ & $\begin{array}{l}\text { Pemahaman } \\
\text { materi dan } \\
\text { modul }\end{array}$ \\
\hline Tahap akhir & $\begin{array}{l}\text { Monitoring dan } \\
\text { Evaluasi }\end{array}$ & $\begin{array}{l}\text { Pendampingan } \\
\text { pelaku usaha } \\
\text { dalam } \\
\text { mengaplikasika } \\
\mathrm{n} \text { keterampilan } \\
\text { manajerial dan } \\
\text { motivasi } \\
\text { usahanya } \\
\text { meningkat }\end{array}$ \\
\hline
\end{tabular}

Dalam pelatihan motivasi kewirausahaan, selain materi juga dengan menggunakan simulasi permainan untuk memotivasi individu dan menampilkan kisah sukses para wirausaha yang dapat menjadi inspirasi bagi para pelaku usaha. Sedangkan pelatihan keterampilan manajerial yang meliputi penyampaian materi mengenai aspek pemasaran, aspek keuangan, aspek operasional/ produksi, aspek sumber daya manusia dilakukan dengan:

a. Teaching. Metode ini merupakan metode transfer knowledge dimana penyampaian materi akan dilakukan satu arah dari fasilitator kepada para peserta.

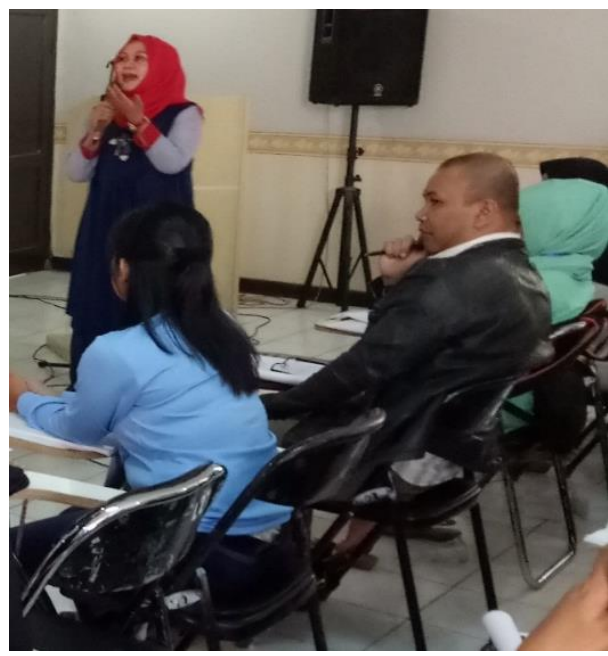

\section{Gambar 1. Proses Teaching pada pengabdian}

b. Teach to Learn. Pada metode ini, peserta akan diberikan waktu untuk menerangkan yang telah diperoleh selama pelatihan kepada peserta lainnya. Hal ini dilakukan dengan keyakinan bahwa peserta telah mengerti materi yang disampaikan fasilitator ketika dapat menerangkannya kepada orang lain.

c. Praktek (latihan). Para peserta akan berlatih melalui pengaplikasian teori yang diperoleh. 


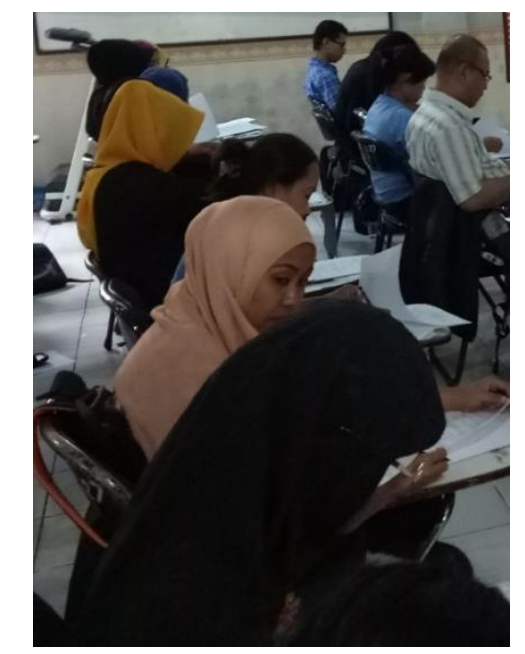

\section{Gambar 2. Peserta Pengabdian Mengerjakan Soal Latihan}

\section{HASIL dan LUARAN}

Pengabdian kepada masyarakat yang telah dilakukan adalah berupa Pelatihan Motivasi Kewirausahaan dan Keterampilan Manajerial Wirausaha Baru yang dilaksanakan di Kecamatan Lengkong Kota Bandung, sebelum pelatihan kami sebagai trainer berupaya menciptakan suasana yang akrab dengan melibatkan seluruh peserta pelatihan agar tercipta dinamika kelompok yang akrab. Suasana pelatihan yang dinamis tidak akan membosankan tentunya akan berpengaruh positif pada proses pembelajaran dalam pelatihan khususnya pelatihan yang diikuti peserta yang telah dewasa.

Setelah tercipta suasana kelas yang kondusif, kemudian dilakukan pelatihan motivasi agar para peserta miliki motivasi untuk berprestasi, khususnya motivasi menjadi pengusaha yang berprestasi, berdaya saing, memilikin keunggulan dan bermental bisnis. Materi yang diberikan lebih menekankan pada motivasi dalam membangun sikap wirausaha dimana para peserta dapat mengenali tujuan dalam menjalankan usahaha, inovasi tiada henti, belajar untuk berubah dan tumbuh, dapat mengembangkan sumbar daya yang terlibat dalam usaha, membangun sistem dalam usaha, membangun jaringan usaha, dan tidak lupa untuk bersyukur terhadap upaya yang telah dilakukan. Selain memberikan materi, juga memberikan paparan berupa kisah kisah wirausaha sukses.

Keterampilan manajeral merupakan keterampilan yang sangat diperlukan untuk usaha, khususnya pada usaha kecil dan menengah, karena dengan keterampilan manajerial mereka dapat mengelola kegiatan usahanya dari aspek pemasaran, aspek sumber daya manusia, aspek produksi dan aspek keuangan. Dalam materi pelatihan manajerial diberikan wawasan mengenai pentingnya 4 (empat) aspek dalam fungsi manajemen yaitu:

a. Aspek Manajemen Pemasaran: pada aspek manajemen pemasran, wawasan yang diberikan berupa bagaimana menjalankan pemasaran yang lebih efektif dengan melakukan segmenting, targeting, dan positiong. Hal ini diperlukan karena usaha yang mereka lakukan pendekatannya masih pada pendekatan produk bukan pada pendekatan pasar. Selain strategi pasar, juga perlu nya taktik pemasaran berupa bauran pemasaran agar para peserta dapat menciptakan, dan juga memasarkan produknya yang diminati konsumen.

b. Aspek Manajemen Produksi. Pada aspek manajemen produksi diberikan pengetahuan mengenai pentingnya kualitas produk, karena pada hakekatnya kegiatan produksi yang berkualitas bukan hanya pada kegiatan pabrikasi saja, tapi juga terdapat pada usaha kecil.

c. Aspek Manajemen Sumber Daya Manusia. Pada aspek manajemen sumber daya manusia diberikan pengetahuan mengenai pentingnya menggali potensi diri, sikap dan perilaku dalam wirausaha.

d. Aspek Manajemen Keuangan. Pada aspek manajemen keuangan, para peserta diberikan pengetahuan mengenai pentingnya pengelolaan keuangan dengan memisahkan 
keuangan pribadi dengan keuangan usaha, karena $90 \%$ peserta pelatihan masih mencampuradukan keuangan pribadi dan usaha. Dalam aspek keuangan juga diberikan pengetahuan mengenai sumber pendanaan, cash flow dan analisis kebutuhan biaya usaha

\section{KESIMPULAN}

Dari pengabdian ini dapat disimpulkan bahwa selama proses palatihan berlangsung mendapatkan respon yang positif dari peserta pelatihan, dimana mereka sangat antusias dalam pembelajaran. Para pelaku usaha mendapatkan pandangan baru mengenai pentingnya motivasi wirausaha dan keterampilan manajerial.

Pelatihan ini diharapkan dapat membatu peserta agar kegitan usaha dapat terus berlanjut (sustainability).

\section{DAFTAR PUSTAKA}

Data Dinas KUMKM Kota Bandung, 2017

http://ekonomi.kompas.com, diunduh pada tanggal 26 januari 2018

Hendro. (2010). Dasar Dasar Kewirausahaan: Panduan Mahasiswa untuk Mengenal, Memahami, dan Memasuki Dunia Bisnis. Jakarta: Erlangga.

Muzinu, M. (2010). Pengaruh faktor-faktor eksternal dan internal terhadap kinerja usaha mikro dan kecil (UMK) di Sulawesi Selatan. Jurnal Manajemen dan Kewirausahaan 12 (1), pp. 33-41.

Profil Kecamatan Lengkong

RPJMD Kota Bandung 2014 - 2018

Tambunan, T.T.H. (2008). "Perkembangan UMKM di Indonesia: Apakah Mereka Digerakkan oleh Jiwa Kewirausahaan?", Center for
Industry, SME and Business

Competition Studies, USAKTI, Jakarta. 